\title{
Evaluation of the Impact of Climatic Factors on Latex Yield of Hevea Brasiliensis
}

\author{
1*Umar, H. Y, ${ }^{2}$ Okore, N.E, ${ }^{1}$ Toryila, M., ${ }^{1}$ Asemota, B., ${ }^{2}$ Okore, I.K \\ ${ }^{1}$ Socio-Economic Division, Research Outreach Department, Rubber Research Institute of Nigeria, \\ PMB 1049, Benin City, Edo State Nigeria \\ ${ }^{2}$ Information and Documentation Department, Rubber Research Institute of Nigeria, PMB 1049, \\ Benin City, Edo State Nigeria
}

\begin{abstract}
Natural Rubber (NR) is a tree crop originated from South America; mainly cultivated for its latex. The first usage of the latex was to rub off pencil marks; hence the name "Rubber" was coined to the substance. The crop gained global awareness since 1876 and its production became widely spread since the $19^{\text {th }}$ century. The first and second World wars however posed some challenges to the crop's cultivation and marketing which led to the discovery of synthetic rubber (SR) by a Russian chemist in 1910. The SR competes with NR in usage. Climatic factors are crucial elements that determine the yield of rubber latex as indicated by earlier studies. In this study, a time-series data for 31 years (1983 - 2013) on statistics of rubber latex yield, temperatures (maximum and minimum), relative humidity (maximum and minimum), rainfall and wind speed were obtained from Tapping and Metrology Units of Rubber Research Institute of Nigeria (RRIN) for analysis. Regression model was used to estimate the specific coefficients of the effects of the seven climatic factors on rubber latex yield in RRIN, Iyanomo, Edo state. The tapping method adopted was half spiral (S/2) and alternate days (d/2) techniques. The results of the findings indicate that $R^{2},(0.643)$ and $F$-value was 5.928. This implies that the $64.3 \%$ of the variation in rubber latex yield in RRIN under the period of review was jointly explained by the independent variables considered in this study (the climatic factors). Specially, the results revealed that Rainfall, Maximum and Minimum Temperature as well as age of rubber plant had positive coefficient, hence were positively correlated with the rubber latex yield, while Wind speed, Maximum and Minimum relative humidity had negative coefficient, thus were inversely correlated with the rubber latex yield in the study area. The study concluded that the need to evaluate the environmental conditions to determine suitable climatic factors for rubber cultivation is paramount; and recommended that whoever wants to go into rubber farming should first endeavour to study the climatic factors of the place and compare with the climatic requirements of rubber available in literature. Planting rubber in marginal climatic requirements of rubber should be experimented first before going into commercial production.
\end{abstract}

Keywords: Rubber yield, climatic factors, coefficients of regression.

\section{INTRODUCTION}

Natural Rubber (Hevea brasiliensis) is an upright tropical deciduous tree. It can grow up to $30-40 \mathrm{~m}$ tall in the wild, and $15-25 \mathrm{~m}$ in cultivation due to the effect of tapping (KewScience Plant of the world). $H$, brasiliensis is cultivated mainly for its product of a milky liquid substance called latex. The genus Hevea is native to South America, where it grows wild in the Amazon and Orinoco Valleys. The discovery of $H$. brasiliensis (HBK) Muell Arg came about through the action of native Indians who used the latex of various plants for making balls, bottles, crude footwear and waterproofing fabric. One of these plants was $\mathrm{H}$. brasiliensis (HBK) Muell Arg, which was later, became the major latex-producing plant based on its desirable qualities since 1495 as reported by Columbus. By 1500 , Mr. Austin Coate defined rubber latex as a milk-like juice, which is found in the bark of Hevea tree that becomes golden brown and thicker on exposure to air. He called the tree a "CAOUTCHOUC," meaning weeping wood (Ogowewo 1986; Umar, Giroh, Agbonkpolor and Mesike, 2011). It was about the same period also that Priestly discovered that the rubber latex could rub off pencil marks, hence the product is named as RUBBER, (Umar, Giroh, Agbonkpolor and Mesike, 2011 and Willy Verheye, 2011). In 1823, MacIntosh made waterproof cloths by coating fabric with rubber dissolved in naphtha. This brought about the first rubber boom, followed by a second one in 1839 after Goodyear and Hancock had discovered the principle of vulcanization, (a process in which rubber is 
heated with sulfur and retains its physical properties once processed into a useful shape), (Willy Verheye, 2011). The search for applications of rubber continues, and one of the most successful applications was in the 1880s when rubber was found to be the basic raw material for tyres used by motor cars. This triggered some people like Wickham and Sir Henry to go into rubber production who in 1876, collected some 70,000 seeds from the Tapajoz valley (Amazone, Brazil) and brought them to Kew Gardens (London) and later to Ceylon in 1876 and Singapore in 1877,(Umar, Giroh, Agbonkpolor and Mesike, 2011; Willy Verheye, 2011). The first rubber plantations in Malaysia were established in 1890. Hevea was introduced in Africa early in the 20th century: in Uganda and Nigeria (1903), Congo (1904), and Liberia in 1924, (by the Firestone Tyre and Rubber Company).

The world rubber market over the past 100 years has been extremely volatile. The First World War hampered the first rubber boom in history which resulted in destruction of large proportion of the plantations and consequent cutting off most of the markets customers in Europe and North America that lead to a drastic price cut. The Second World War created another problem in the sense that most Asian plantations fell into the hands of the Japanese and were cut the second time from their major consumer markets. This led to the discovery of synthetic rubber in 1910 by the Russian chemist Sergei Lebedev and the creation of a new synthetic rubber industry, mainly in the United States. The synthetic rubber (SR) started competing with natural rubber (NR) in the world markets for usage.

Natural Rubber (Hevea brasiliensis) is nowadays cultivated as far north as $25^{\circ}$ North (Yunnan Highlands, China) and as far south as $21^{\circ}$ South in Brazil. The main production zone, worldwide, is however concentrated between $15^{\circ} \mathrm{N}$ and S. For South East Asia and the South Pacific this includes Malaysia, Indonesia, Thailand, Sri Lanka, South India, Cambodia, Vietnam, The Philippines, PapuaNew Guinea and Southern China. There are important plantations also in Central and West Africa (Congo, Cameroon, Ivory Coast, Liberia, Nigeria), while rubber cultivation in tropical America is concentrated over a small area between $10^{\circ} \mathrm{N}$ and S, (Willy Verheye, 2011).

Climate plays a dominant role in agriculture which has a direct impact on the productivity of crops and vegetations as Mesike and Esekhade (2013), reported that climatic factors influence farming outputs at any stage from cultivation through the final harvest. Generally, there are many factors influencing crop production and these include soil, climate and diseases among others with rainfall being the dominant variable in tropical agriculture as solar radiation, wind, temperature, relative humidity and other climatic parameters highly influenced by precipitation and generally determine the global distribution of crops and livestock as well as their productivity. Mesike and Esekhade (2013), cited Olaoye, 1999, that regular occurrence of drought as a result of erratic climate change which affect the weather elements such as rain distribution during the growing season reduce Nigeria's capability for increased crop production. It was also reported that high rainfall tended to decrease tapping days per year in rubber plantation (Akinbobola, et al, 2015).

Climate thus affects agricultural products either positively or negatively. For instance, Akinbobola, et $a l$, (2015) reported that an estimated cost of the deforestation and losses in non timber forest products in the last five decades in Nigeria was put at N120 billion per year, or 1.7\% of GDP in 2003. The effect of climatic factors on rubber latex yield in South-East Nigeria was also evaluated by Omokhafe and Emuedo (2006). Their findings indicated that highest latex yield was obtained from October to December compared to other months of the year. The study also revealed that the minimum temperature was directly proportional to latex yield while there was a negative correlation between maximum temperature and latex yield. They attributed the effect to the fact that higher temperatures result in high evapo-transpiration rates of the rubber plant which could reduce net accumulation of photosynthates. Their findings on latex yield in relation to relative humidity (rh), was positively correlated. They opined that combination of maximum temperature and relative humidity are critical factors when selecting sites in non-traditional rubber zones. Their study also revealed a positive correlation between rainfall and latex yield. The study was concluded with a suggestion for a further research to determine the specific coefficients of the effects of climatic factors on rubber latex yield in Nigeria, hence the purpose of this study.

Available literature revealed that yield of rubber is largely dependent on the cultivar planted and the agro-management inputs given to the trees during the periods of immaturity and production (Ajokporise and Akpere, 2010). Yield can also, be stimulated by applying ethylene-releasing 
chemicals (e.g. ethephon) on the tapping cut of young trees and on the bark of older trees either directly below (downward tapping) or above (upward tapping) the tapping cut.

The objective of this study was therefore to evaluate the specific coefficients of the impact of the seven climatic factors on rubber latex yield in Iyanomo, Rubber Research Institute of Nigeria, Benin City, Edo State using regression analyses models as well as descriptive statistics.

\section{METHODOLOGY}

The study used a Time-Series data obtained for 31 years (1983 - 2013) from Tapping and Metrology Units of Rubber Research Institute of Nigeria (RRIN). The international method of tapping cut (length of the cut) and frequency were adopted; that is, the fraction of the circumference was half spiral (S/2) while frequency of tapping was alternate day tapping $(\mathrm{d} / 2)$. The Institute has both exotic and RRIN developed rubber clones. Information on Rainfall $(\mathrm{mm})$, Temperature (minimum and maximum) $\left({ }^{\circ} \mathrm{C}\right)$, wind speed $(\mathrm{km} / \mathrm{h})$, Relative Humidity (minimum and maximum) $(\%)$ and quantity of rubber latex yield (lt.) produced during the period under review.

The data collected were subjected to regression models supported by descriptive statistical analyses such as mean, minimum and maximum parameters. The regression models were: linear, semi-log and Cobb-Douglas analysis using Ordinary Least Square (OLS) method. The explicit function is expressed as:-

$\mathrm{Y}=\mathrm{f}\left(\mathrm{X}_{1}, \mathrm{X}_{2}, \mathrm{X}_{3}, \mathrm{X}_{4}, \mathrm{X}_{5}, \mathrm{X}_{6}, \mathrm{X}_{7}, \mu\right)$

Where:

$\mathrm{Y}=$ Total Quantity of Rubber Latex produced (lt.)

$\mathrm{X}_{1}=$ Years under review,

$\mathrm{X}_{2}=$ Rainfall $(\mathrm{mm})$

$\mathrm{X}_{3}=$ Minimum Temperature $\left({ }^{\circ} \mathrm{C}\right)$,

$\mathrm{X}_{4}=$ Maximum Temperature $\left({ }^{\circ} \mathrm{C}\right)$,

$\mathrm{X}_{5}=$ Wind speed $(\mathrm{km} / \mathrm{h})$,

$\mathrm{X}_{6}=$ Minimum Humidity (\%), and

$\mathrm{X}_{7}=$ Maximum Humidity $(\%)$.

The three functional models (linear, Semi- log and Cobb - Douglas) were tried; and using the economic theory, statistical criteria and coefficient of multiple determinations $\left(\mathrm{R}^{2}\right)$, the best regression result based on the best line fit was selected for interpretation of the study as adopted by Maiangwa (2007) and, Umar (2014). The functional models are:

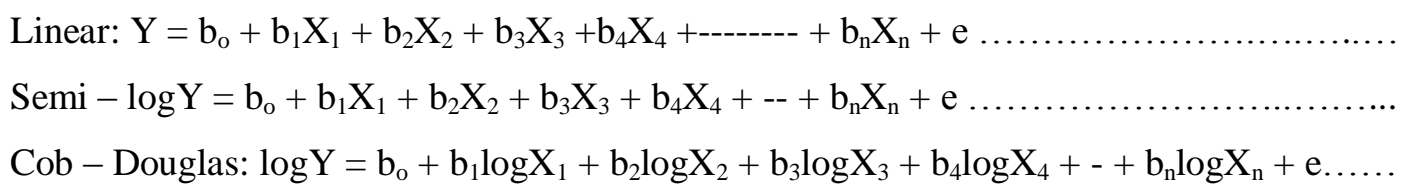

Where:

$\mathrm{b}_{\mathrm{o}}=$ constant

$b_{1}-b_{n}=$ coefficients,

$\mathrm{Y}=$ dependent variables,

$\mathrm{X}_{1}-\mathrm{X}_{\mathrm{n}}=$ independent variables, and

$\mathrm{e}=$ error term.

\section{RESULTS AND DISCUSSION}

Among the production function models, the linear functional model happened to be the lead equation among the three models, having the best fit (Table 1). It has a coefficient of multiple determinant $\left(\mathrm{R}^{2}\right)$ value of 0.643 and $\mathrm{F}$ - value of 5.928 . 
Table 1. Regression Result on the influence of climatic factor on the yield of rubber latex

\begin{tabular}{|ll|l|l|l|}
\hline Independent Variables & & Coefficient & T - value & Sig. level \\
\hline Constant & & -5.165 E6 (2.393E6)® & -2.158 & 0.042 \\
Year (Age of plantation) & $\left(\mathrm{X}_{1}\right)$ & $2903.091(1319.096)$ & 2.201 & 0.038 \\
Rainfall & $\left(\mathrm{X}_{2}\right)$ & $924.335(359.519)$ & 2.571 & 0.017 \\
Minimum Temperature & $\left(\mathrm{X}_{3}\right)$ & $3366.708(7852.093)$ & 0.429 & 0.672 \\
Maximum Temperature & $\left(\mathrm{X}_{4}\right)$ & $324.502(39660.283)$ & 0.082 & 0.935 \\
Wind Speed & $\left(\mathrm{X}_{5}\right)$ & $-11112.193(8188.329)$ & -1.357 & 0.188 \\
Minimum Humidity & $\left(\mathrm{X}_{6}\right)$ & $-4815.979(3945.342)$ & -1.221 & 0.235 \\
Maximum Humidity & $\left(\mathrm{X}_{7}\right)$ & $-2081.291(853.651)$ & -2.438 & 0.023 \\
$\mathbf{R}^{2}$ & & $\mathbf{0 . 6 4 3}$ & & \\
F- Value & & $\mathbf{5 . 9 2 8}$ & & \\
\hline
\end{tabular}

Dependent Variable $=$ Rubber Latex yield

( $)=$ error terms

Source: Calculated from Secondary data, 2017

The model was thus selected and used for explanations of the impact of the climatic factors considered in this study. The $\mathrm{R}^{2}$ value of 0.643 implies that $64.30 \%$ of the variations in rubber latex yield in RRIN under the period of review was jointly explained by the independent variables considered in this study, while the remaining $35.7 \%(100-64.30)$ was not explained by the model which could either be due to non-inclusion of some important independent variables in the model or might be due to the error in the model estimation (error term). The result for Years (Age of plantation) under review $\left(\mathrm{X}_{1}\right)$ has positive coefficient (2903.091) and significant at 5\% level of probability. This implies that age of plantation has direct relationship with the volume of rubber latex yield. That is, with increase in the age of rubber plantation, the higher the latex yields (ceteris paribus). This corroborates the finding of Eregha et al, (2014) and KewScience Plant of the world, which state that rubber latex yield increases as from the time of tapable age up to 15 years and becomes economically unproductive after 35 years of age. The positive sign of the coefficient (2903.091) implies that each increase in number of years will lead to an increase in the volume of rubber latex by 2903.091 milliliters ceteris paribus.

Similarly, rainfall $\left(\mathrm{X}_{2}\right)$ had positive coefficient (924.335) and statistically significant at $5 \%$ level of probability hence has direct relationship with the rubber latex yield. From the result of analysis, it implies that a 1mililiter increase of water volume will lead to a proportional increase of 924.335 milliliter of rubber latex until the optimal level is reached as most plants (rubber inclusive) do not like waterlogged soils. The average volume of rainfall recorded under period of review was 172.204 $\mathrm{mm} / \mathrm{annum}$. The highest volume of rainfall experience during the time under review was $229.78 \mathrm{~mm}$ in the year 2012, while the least was $124.89 \mathrm{~mm}$ in 1983. With other climatic factors come to play, the rubber latex yield recorded least in 1983 This corroborates the apriority expectation as latex contains high volume of water which the rubber plant absorbed from soil via it roots. This also agrees with the findings of Omokhafe and Emuedo (2006) and Mesike and Esekhade (2013), who said that rainfall, among other factors, has direct influence on how land is used. The volume of rainfall determines the vegetation and crop distribution globally.

The relationship of minimum and maximum temperatures $\left(\mathrm{X}_{3}\right)$ and $\left(\mathrm{X}_{4}\right)$ respectively with rubber latex yield were positive $\left(X_{3}=3366.708\right)$ and $\left(X_{4}=324.502\right)$ and both were not significant. These however also imply that a unit degree increase in temperature will result to an increase in latex yield by about 3366 and 325 for $\mathrm{X}_{3}$ and $\mathrm{X}_{4}$ milliliters respectively. This disagrees with the findings of Omokhafe and Emuedo (2006). These results for minimum and maximum temperatures during the period under review show that at the average minimum temperature there was higher value of 3366 compared to the value of 325 at the average maximum temperature. This implies that the optimal temperature requirement for optimal latex yield in the study area fell between the two coefficients of $X_{3}$ and $X_{4}$. This is further explained in Table 2.

The variable wind speed $\left(\mathrm{X}_{5}\right)$, has negative coefficient of $(-11112.9)$ and is not significant. It however implies that a unit increase in wind speed will lead to decrease in rubber latex yield by about 11113 millimeters and vice versa. The coefficients of maximum $\left(\mathrm{X}_{6}\right)$ and minimum $\left(\mathrm{X}_{7}\right)$ humidity also have negative values (- 4815.979) and (- 2081.291) respectively with maximum humidity being significant at $5 \%$ level of probability. This implies that maximum humidity decreases rubber latex yield by about 2081 milliliters. Table 2 shows the summary of the climatic factors on the effects of 
rubber latex yield in RRIN during the period under review. The Table depicts that maximum yield of rubber latex was realized in 2013 (243,543.23 liters), while the least was in 1983 (4,620.73 liters).

Table 2. Summary of the Effects of Climatic factors on Rubber Latex yield

\begin{tabular}{|l|l|c|l|c|c|c|c|c|}
\hline Parameters & Rainfall & $\begin{array}{l}\text { Min. } \\
\text { Tempt. }\end{array}$ & $\begin{array}{l}\text { Max. } \\
\text { Tempt. }\end{array}$ & $\begin{array}{l}\text { Wind } \\
\text { speed }\end{array}$ & $\begin{array}{l}\text { Min. } \\
\text { Humidity }\end{array}$ & $\begin{array}{l}\text { Max. } \\
\text { Humidity }\end{array}$ & $\begin{array}{l}\text { Latex } \\
\text { Yield }\end{array}$ & Year \\
\hline Average & 172.204 & 22.800 & 30.523 & 26.071 & 60.388 & 76.781 & 140842.476 & 1998 \\
Minimum & 124.89 & 21.1 & 21.9 & 23.5 & 53.87 & 60.7 & 4620.73 & 1983 \\
Maximum & 229.78 & 26.25 & 32.2 & 28.3 & 62.6 & 99.9 & 243543.23 & 2013 \\
TOTAL & $\mathbf{5 3 3 8 . 3 1}$ & $\mathbf{7 0 6 . 7 9}$ & $\mathbf{9 4 6 . 2}$ & $\mathbf{8 0 8 . 2}$ & $\mathbf{1 8 7 2 . 0 4}$ & $\mathbf{2 3 8 0 . 2}$ & $\mathbf{4 3 6 6 1 1 6 . 7 5}$ & 31 years \\
\hline
\end{tabular}

Source: Calculated from Secondary data, 2017

This implies that during the period under review, the climatic factors in 2013 were the best for rubber latex yield and those of 1983 was worse. This agrees with many studies which states that rubber tree (Hevea brasiliensis) thrive worldwide in the humid tropics with optimum weather conditions of $\pm 28^{\circ} \mathrm{C}$ mean annual temperature, relative humidity of $67-82.3 \%$, rainfall of $1400-4000 \mathrm{~mm}$ distributed over 100-182 days (Kpolo, 1999; RRIS, 2002;Omokhafe and Emuedo, 2006; Rubber Asia, 2006, Umar, et al, 2011).

\section{CONCLUSION}

Climatic factors (rainfall, temperature, wind speed and relative humidity) have significant influence on the rubber latex yield; hence the need to evaluate the environmental conditions to determine whether or not the place is suitable for cultivation.

\section{RECOMMENDATIONS}

Rubber farmers should endevour to study the climatic factors of any place they want to plant rubber for the purpose of having high latex yield. Thus planting rubber in marginal soil and climatic requirements of rubber should only be experimented first before going into large scale production.

\section{REFERENCES}

[1] Ajokporise, D. and Akpere, I.P. (2010). Constraints to rubber production in Sapele Local Government Area of Delta State, Nigeria. Journal of Research in National Development. Vol. 8 (2).

[2] Akinbobola, T.O; Adedokun, S.A and Nwosa P.I (2015). The impact of climate change on composition of agricultural output in Nigeria. American Journal of Environmental Protection. 3 (2), $44-47$.

[3] kewScience Plant of the world, online_kewscience.htm. hevea bresiliensis (wold.ex.A.Juss) Muell. Arg.

[4] Eregha, P.B,Babatolu, J.S and Akinnubi, R.T. (2014). Climate Change and Crop Production in Nigeria: An Error correction Modelling Approach. International Journal of Energy and Policy. 4(2), $297-311$.

[5] Kenneth, O. Omokhafe and Okeoghene, A. Emuedu. (2006). Evaluation of Five Weather Characters on Latex Yield in Hevea brasiliensis. International Journal of Agricultural Research; $1 ; 234-239$.

[6] Kpolo, D.M. (1999). Natural rubber production in Africa. The Rubber International Magazine 1: pp. $55-61$.

[7] Maiangwa, M.G. (2007). Factors Associated with the Adoption Animal Manure in the NorthWest zone of Nigeria. Nigerian Journal of Tropical Agriculture Vol.9: P 91-110.

[8] Mesike, C.S and Esekhade, T.U (2013). Rainfall Variability and Rubber Production in Nigeria. African Journal of Environmental Science and Technology. 8(1), 54 - 57.

[9] Ogowewo N (1986). Marketing strategies for natural rubber seed oil and caked, In: Industrial

[10] Utilization of Natural Rubber Seed, latex and wood. Rubber Research Institute of Nigeria Benin City. Pp 109-112.

[11] Olaoye, (1999). Developing Draught tolerant varieties for the Savanna Agro-ecologies of

[12] Nigeria in $25^{\text {th }}$ year commemorative poblications of Genetic Society of Nigeria. $173-183$. 
[13] Rubber Asia (2006). The complete magazine on rubber. November -December; pp 177.

[14] Rubber Research Institute of Srilanka, RRIS (2002). Annual Review, pp 172.

[15] Umar, Giroh, Abonkpolor and Mesike, (2011). An Overview of World Natural Rubber Production and Consumption: An Implication for Economic Empowerment and Poverty Alleviation in Nigeria. Journal of Human Ecology, 33(1): 53-59.

[16] Umar H (2014). Economic Analysis of Gum Arabic Marketing in North - Eastern Nigeria. A $\mathrm{PhD}$ Thesis submitted to the Department of Agricultural Economics and Extension, Kogi State University, Anyigba, Nigeria.

[17] Verheye, Willy ( 2010). Growth and production of rubber. In: Verheye, W. (ed.), Land Use, Land Cover and Soil Sciences. Encyclopedia of Life Support System (EOLSS), UNESCOEOLSS Publishers, Oxford, UK, http://www.eolss.net 